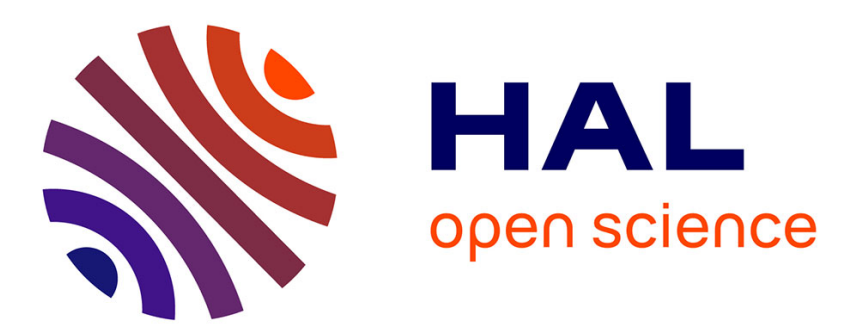

\title{
Effect of fresh and mature organic amendments on the phytoremediation of technosols contaminated with high concentrations of trace elements
}

Nour Hattab, Mikael Motelica-Heino, Olivier Faure, Jean Luc Bouchardon

\section{- To cite this version:}

Nour Hattab, Mikael Motelica-Heino, Olivier Faure, Jean Luc Bouchardon. Effect of fresh and mature organic amendments on the phytoremediation of technosols contaminated with high concentrations of trace elements. Journal of Environmental Management, 2015, 159, pp.37-47. 10.1016/j.jenvman.2015.05.012 . insu-01167311

\section{HAL Id: insu-01167311 https://hal-insu.archives-ouvertes.fr/insu-01167311}

Submitted on 18 Mar 2016

HAL is a multi-disciplinary open access archive for the deposit and dissemination of scientific research documents, whether they are published or not. The documents may come from teaching and research institutions in France or abroad, or from public or private research centers.
L'archive ouverte pluridisciplinaire $\mathbf{H A L}$, est destinée au dépôt et à la diffusion de documents scientifiques de niveau recherche, publiés ou non, émanant des établissements d'enseignement et de recherche français ou étrangers, des laboratoires publics ou privés. 


\title{
Effect of fresh and mature organic amendments on the phytoremediation of technosols contaminated with high concentrations of trace elements
}

\author{
Nour HATTAB ${ }^{\mathrm{a}, \mathrm{b}^{*}}$, Mikael MOTELICA-HEINO ${ }^{\mathrm{a}}$, Olivier FAURE ${ }^{\mathrm{c}}$ and \\ Jean-Luc BOUCHARDON ${ }^{\mathrm{c}}$
}

\footnotetext{
${ }^{a}$ ISTO, UMR 7327 - CNRS/Université d'Orléans, Campus Géosciences, 1A, rue de la Férollerie, 45071 Orléans cedex 2, France. E-mail : nour.hattab@univ-orleans.fr
}

\begin{abstract}
${ }^{b}$ Université d'Orléans, UFR-Faculté des Sciences, Laboratoire de Biologie des Ligneux et des Grandes Cultures, UPRES EA 1207, rue de Chartres, BP 6759, F-45067 Orléans Cedex 02, France.

${ }^{\mathrm{c}}$ Ecole Nationale Supérieure des Mines de Saint-Etienne, Département SPIN, Laboratoire GéoSciences \& Environnement, 158 cours Fauriel, F-42023, Saint Etienne Cedex 2, France
\end{abstract}

\begin{abstract}
Organic compounds resulting from the decomposition of organic amendments are used in the remediation of trace element (TE) contaminated soils. The mobility, phytoavailability and soil exposure intensity of molybdenum (Mo), chromium $(\mathrm{Cr})$, zinc $(\mathrm{Zn})$, copper $(\mathrm{Cu})$, Cobalt $(\mathrm{Co})$ and Arsenic (As) were evaluated in the phytoremediation of contaminated technosols after the addition of two organic matter types, fresh ramial chipped wood (RCW) and composted sewage sludge (CSS). The experiment consisted of nine main treatment blocks: (A) 3X unamended soil (NE), (B) 3X soil amended with RCW and (C) 3X soil amended with mature CSS. Total dissolved TE concentrations were determined in soil pore water (SPW) sampled by Rhizon samplers. The soil exposure intensity was assessed by standard Chelex 100 DGT (diffusive gradient in thin films) probes. TE phytoavailability was characterized by growing dwarf beans on potted soils and analyzing their foliar TE concentrations. The results of the present study indicate that the addition of fresh RCW and CSS has a positive effect on contaminated technosols. RCW decreased the mobility of all the studied TE in the SPW, whereas CSS reduced the mobility of Mo, Cr and Co, while it increased the mobility of Zn, $\mathrm{Cu}$ and As compared with the NE soil.
\end{abstract}


The Zn soil exposure intensity assessed by DGT was not significantly changed by the addition of RCW and CSS, while the Cr soil exposure intensity was significantly decreased after RCW addition compared with the soil treated with CSS and the NE soil. In contrast $\mathrm{Cu}$ and $\mathrm{Co}$ were non labile in the three soils. Both RCW and CSS decreased the foliar concentration and the mineral mass of $\mathrm{Mo}, \mathrm{Zn}, \mathrm{Cr}$, $\mathrm{As}$ and $\mathrm{Co}$ in the bean leaves but increased the foliar $\mathrm{Cu}$ concentration.

Key words: Soil contamination, phytostabilisation, Trace elements, Organic amendment, Mobility, phytoavailability, soil exposure intensity

\section{Introduction}

Among anthrosols, technosols and hortic, anthrosols are considered to be the most exposed to pollution (Bulgariu et al., 2007; Thornton, 1991: Florea and Munteanu, 2003, IUSS, 2006). The high concentration, distribution and migration of TE in these soils represent an important environmental problem due to the great toxicity of these elements that may cause major perturbations to soil ecosystems (Jamil et al., 2014; Alloway, 1995; Kabata-Pendias and Pendias, 1992; Ross, 1994). In fact the high concentrations of TE in the contaminated anthrosols is more problematic than for other soils because most of the properties of these types of soil may change with time, making their handling more difficult (Kelly et al., 1996). Therefore to limit the solubility and the bioavailability of metal(oid)s in contaminated anthrosol a special soil-management techniques is required. Several treatment techniques can be used to remediate TE contaminated soils. These techniques include physical and chemical remediation, and agro-ecological engineering methods such as phytoremediation (Chen et al., 1999; Chen et al., 2000 a, b). Conventional soil reclamation technologies such as 'dig and dump', soil washing, and sieving are effective but destructive thus not sustainable in terms of consumption of raw materials and waste production (Raicevic et al., 2005; Dermont et al., 2008). In addition, they are very expensive, particularly for large contaminated sites. Less invasive, low-cost phytotechnologies such as phytostabilization, singly and in combination with in situ stabilization (i.e. assisted phytostabilization), are potential management options to restore the physical, chemical and biological properties of TE contaminated soils (Mench et al., 
2000; Bolan and Duraisamy, 2003; Pérez de Mora et al., 2005; Raicevic et al., 2005; Kumpiene et al., 2006, 2008; Segura and Ramos 2013).

Several mineral and organic amendments can improve phytostabilization and the production of plant by decreasing the solubility, leaching and bioavailability of TE (Brown et al., 2004; Basta and McGowen., 2004; Kumpiene et al., 2008; Mench et al., 2010; Angelova et al., 2013). The immobilizing effect of such amendments are thought to act through various complex processes $e . g$. adsorption onto mineral surfaces, formation of stable compounds with organic ligands, surface precipitation and ion exchange (Kumpiene et al., 2008; Ahmad et al., 2011). However, these processes are still not well understood and the choice of a particular amendment is often problematic. Thus, case studies assessing the mobility and bioavailability of TE in contaminated soils managed by assisted phytostabilization are needed to better define the pros and cons of such management options (Mench et al., 2010).

Organic matter (compost, manure or various organic wastes) additions to soil have long been considered important in maintaining the quality of both natural and managed soils, principally because of their capacity to provide nutrients to the soil's living organisms and through their influence on the soil physical properties. This influence on soil properties depends on several factors such as the quantity, type and maturation of the organic matters applied to the soil and the soil properties. Moreover organic amendments may enhance the soil fertility and microbial activity, leading to the amelioration of the soil quality as a whole. These overall modifications generally decrease the mobility and the bioavailability of TE, even if temporarily, and thus promote the reestablishment of vegetation and increase plant growth (Castaldi and Melis, 2004; Madejón et al., 2006; Branzini and Zubillaga, 2012).

Nevertheless, the effect of organic amendments on the mobility and the bioavailability of metal(loid)s depends on the nature of the organic matter itself, its microbial degradability, its effects on soil chemical and physical proprieties, as well as on the particular soil type and metal(loid)s concerned (Walker et al.., 2003, 2004; Angelova et al., 2013). However very few comparative studies have been performed so far and the choice of a particular organic amendment in assisted phytostabilization strategies often remain empirical.

The main aim of this work was to assess the effect of two different organic amendments (composted sewage sludge (CSS) and fresh ramial chipped wood (RCW)) on the mobility, phytoavailability and soil exposure intensity of several TE in a metallurgical technosol remediated by assisted phytostabilization. 


\section{Materials and methods}

\subsection{Site description and experimental design}

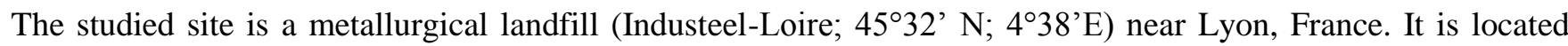
behind a steel and iron factory which is still in activity. Site description and experimental design were previously reported in Hattab et al, 2014a.

The main chemical and physical properties and the total metal concentrations measured in the RCW and CSS before being mixed with the technosol are given in table 1. The main pedological characteristics of the soils studied (taken at $0-20 \mathrm{~cm}$ depth) are given in table 2. Their total metal concentrations are given in table 3 . The average concentration values of metals measured in the soil were $5837 \mathrm{mg} \cdot \mathrm{kg}^{-1} \mathrm{Cr}, 620 \mathrm{mg} \cdot \mathrm{kg}^{-1} \mathrm{Mo}, 1464 \mathrm{mg} \cdot \mathrm{kg}^{-1} \mathrm{Zn}, 444$ mg.kg ${ }^{-1} \mathrm{Cu}$ and $80 \mathrm{mg} \cdot \mathrm{kg}^{-1}$ As (Table 3). These TE concentrations are well above the limits of TE concentrations measured in natural unpolluted French soils (Baize, 2000), which confirms the existence of a very high polymetallic contamination.

\section{Table 1}

Table 2

Table 3

\subsection{Assessment of TE (phyto)availability}

TE (phyto)availability in the studied soils was assessed using three different approaches: $i /$ the measurement of growth inhibition and TE accumulation in Phaseolus vulgaris; iil the measurement of metal concentration in the soil pore water; and iii/ the diffusive gradient in thin films (DGT) method to assess the TE soil exposure intensity. 


\subsubsection{Growth inhibition and TE accumulation in Phaseolus vulgaris}

Soil samples were collected in May 2011, i.e 18 months after ploughing and soil enrichment with RCW and CSS amendments. Each soil sample (approx. $3.0 \mathrm{~kg}$ ) was made of six independent sub-samples (approx. $0.5 \mathrm{~kg}$ ) randomly taken from the surface soil $(0-25 \mathrm{~cm})$ at each of the nine experimental plots. The nine samples $(3 \times \mathrm{RCW}, 3 \mathrm{x}$ CSS and $3 \mathrm{x} \mathrm{NE}$ ) were sieved at $2 \mathrm{~mm}$. One kilo of each soil was then placed in $1.5 \mathrm{~L}$ pots $(15 \mathrm{~cm} \mathrm{D} \mathrm{X} 14 \mathrm{~cm} \mathrm{~L})$, and watered up to $80 \%$ of the water holding capacity (WHC) with addition of deionized water. Four dwarf bean seeds (Phaseolus vulgaris L. cv. Contender) were then sown in each pot and cultivated under controlled conditions $(16 \mathrm{~h} \mathrm{light/8 \textrm {h }}$ darkness, $25^{\circ} \mathrm{C} / 21^{\circ} \mathrm{C}, 150 \mu \mathrm{mol} \mathrm{m} \mathrm{m}^{-2}, 65 \%$ relative humidity (ISO, 2005)). The conditions of culture and the digestion of primary bean leaves (BL) have been previously published in Hattab et al. 2014b.

\subsubsection{Extraction and characterization of SPW}

Soil moisture samplers (model MOM, Rhizosphere Research Products, Wageningen, The Netherlands), hereafter called rhizons, were used to extract the SPW from each pot. Rhizons were cleaned with $5 \% \mathrm{HNO}_{3}$ and carefully washed with deionized water before use. Three rhizons were placed at $45^{\circ}$ in each pot during potting. After 15 days of bean culture, rhizons from each pot were left under vacuum for 24 hours (Cattani et al., 2006) to collect the soil pore solution $\left(\approx 30 \mathrm{~mL}\right.$ per pot). Three aliquots $(3 \mathrm{ml})$ of the soil solution from each pot were acidified with $\mathrm{HNO}_{3}$ (final concentration: $\left.0.1 \mathrm{~mol} . \mathrm{L}^{-1}\right)$ for metal analyses. Additionally, three aliquots $(1.5 \mathrm{ml})$ were kept untreated for measurements of dissolved organic carbon (DOC). The SPW solutions were stored at $4 \mathrm{C}^{\circ}$ until analyses.

\subsubsection{DGT measurements}

The potentially available TE concentrations $\left(\mathrm{C}_{\mathrm{DGT}}\right)$ or soil exposure intensity were determined using standard Chelex-100 cylindrical DGT units (DGT Research, Lancaster, UK) with an active surface area of $3.14 \mathrm{~cm}^{2}$. These DGT devices (Zhang et al., 2001) consisted of a Chelex 100 binding resin layer and a polyacrylamide diffusion gel layer covered with a $0.45 \mu \mathrm{m}$ filter membrane (Davison et al., 2000; Ernstberger et al., 2002)..

Two DGT probes were manually inserted into the humid topsoil $(80 \% \mathrm{RCW})$ of each pot, just after the bean harvest. After a $24 \mathrm{~h}$ period, metals accumulated in the resin-gel layer were extracted by immersion for $24 \mathrm{~h}$ in $1 \mathrm{~mL}$ of $5 \% \mathrm{HNO}_{3}$. This solution was further diluted 10 times before TE analysis. 


\subsection{Measurements of TE in bean extracts, SPW and DGT probes}

TE concentrations were determined by HR-ICP-MS (Element 2, Thermo Fischer, Waltham, USA) using a Twinnabar cyclonic spray chamber and a Micromist nebulizer (Glass Expansion, Melbourne, Australia). The accuracy and precision of analyses were checked by performing calibrations with a standard reference water solution (1000 ppm, Fisher scientific).

For the primary $\mathrm{BL}$ digests, six $\mathrm{TE}(\mathrm{As}, \mathrm{Co}, \mathrm{Cr}, \mathrm{Cu}, \mathrm{Mo}$ and $\mathrm{Zn}$ ) were analyzed. Four repeated measurements were performed for each digest, generating 36 test results (4 replicates x 9 digests). Total TE concentrations in leaves were first determined on a $\mu \mathrm{g}$ TE/g DW (dry weight) basis. In addition, the mineral masses (expressed in $\mu \mathrm{g}$ TE/pot) were calculated by multiplying the element concentration in leaves by the total DW of the harvested material.

For the SPW solutions extracted with Rhizon samplers, the same TE (As, Co, Cr, Cu, Mo and $\mathrm{Zn}$ ) were analyzed. Results were expressed on a $\mu \mathrm{g}$ TE/L soil solution basis.

Lastly, for the TE extracted with DGT probes, only $\mathrm{Co}, \mathrm{Cu}, \mathrm{Cr}$ and $\mathrm{Zn}$ concentrations were determined because of the selectivity of the chelex 100 resin. The total mass of metal (M) accumulated per unit area of the DGT probe over its deployment time $(\mathrm{t})$ was calculated as previously reported in Hattab et al. 2014b.

\subsection{Measurements of total and dissolved organic carbon}

Total organic carbon (TOC) in the soils studied was determined using a Rock-Eval 6 apparatus (Vinci Technologies; Espitalié et al. (1985a, b) and Lafargue et al. (1998)). This instrument uses a ramped temperature pyrolysis technique, where a small amount of material (70 -100 mg) is heated in an inert atmosphere (helium or nitrogen) and combusted with air, to measure several key geochemical parameters, including TOC. Measurements of TOC were performed in samples taken from the potted soils, just before bean sowing, and after drying the soil at $105 \mathrm{C}^{\circ}$ and milling it very finely to obtain homogeneous samples.

Dissolved organic carbon (DOC) was measured in SPW collected with Rhizon samplers. Analyses were performed with a Shimadzu ${ }^{\odot}$ TOC 5000A carbon analyzer. The accuracy of the instrument was checked by performing 
calibration with a standard reference solution of potassium hydrogen phthalate (KHP) at a concentration of $1000 \mathrm{mg}$ Carbon/L. Four repeated measurements of DOC were performed for each SPW solution.

\subsection{Other measurements}

The $\mathrm{pH}$ and electric conductivity (EC) of the studied soils were measured at the beginning of the experiment, before bean sowing. Measures were performed in deionized water with a soil:water ratio of 1:2.5 (S: W)(NF ISO 10390). $\mathrm{pH}$ and EC were also determined in the SPW solutions taken with Rhizon samplers. Additionally, the concentrations of major cations $\left(\mathrm{Na}^{+}, \mathrm{K}^{+}, \mathrm{Ca}^{2+}\right.$, and $\left.\mathrm{NH}_{4}^{+}\right)$and anions $\left(\mathrm{NO}_{3}^{-}, \mathrm{SO}_{4}^{2-}\right.$, and $\left.\mathrm{Cl}^{-}\right)$were determined by ion chromatography (Dionex ICS-2000, Sunnyvale, CA), using a CS16A column for cations and a AS17 column for anions.

\subsection{Statistical analyses}

One-way analysis of variance (ANOVA), followed by Tukey post hoc comparisons were performed on the total dissolved SPW concentrations, DGT concentrations, R ratios, foliar element concentrations, foliar mineral masses and primary bean leaf DW yields to evaluate the influence of the treatment on TE (phyto)availability. Pearson correlation coefficients (linear regression) between soil, SPW and plant parameters were also calculated. Differences were considered statistically significant at $p<0.05$. All statistical analyses were performed using the Statistica V. 6 software (StatSoft).

\section{Results}

\subsection{SPW characteristics}

Table 4 shows the physico-chemical characteristics of the soil (i.e. TOC) and SPW (pH, DOC, EC and the concentrations of major cations and anions) determined for the treated (RCW and CSS) and the untreated subplots (NE) one year after the addition of organic amendments. The table presents the average values and standard deviations for the nine plots ( 3 replicates X 3 types of soil). The experiments reveal that the additions of the organic amendments (RCW and CSS) in the soils have several effects. 
First the soil $\mathrm{pH}$ did not change significantly between the treated and untreated soils $(\mathrm{p}>0.05)$; it decreased slightly by $3 \%$ in the soil treated with RCW and CSS compared to the untreated soil (NE). Similar results were found by Vaca et al. (2011) who investigated the effect of CSS on the soil properties and TE mobility. They found that the addition of CSS decreased the soil pH slightly by 3\% compared with the control soil. Likewise Soumaré et al. (2006) who studied the effect of RCW and litter compost (LC) on contaminated soil properties, found that RCW decreased the soil pH slightly by $3 \%$ compared with the control soil.

Secondly, the values of the DOC increased by 2 and 4 fold, the TOC by 2 and 3.5 fold and the EC by 1.8 and 1.3 fold for the RCW and CSS treated soils respectively compared with the untreated soil (NE). Vaca et al. (2011) also found that the addition of CSS to the soil increased its soil organic matter (SOM) content by 2 fold compared to the soil without amendments, while Soumare et al. (2006) found that the application of RCW to the soil increased the quantity of SOM in the soil by 2 fold compared with the control soil. Bragato et al. (1998) investigated two types of organic amendment (dehydrated sludge and sewage sludge compost (SSC)) on a salty loam soil. They found that the application of a dehydrated sludge and SSC compost increased the soil TOC-content (from 0.71 to $0.86 \%$; i.e. a relative increase of $21 \%)$ compared with the control soil. Additionally, soil amendments had an impact on the cation and anion concentrations in the SPW. We can note that the addition of the RCW and CSS decreased the concentrations of anions and some cations such as $\left(\mathrm{Cl}^{-}, \mathrm{NO}^{-}, \mathrm{SO}^{2-}, \mathrm{PO}^{3-} ; \mathrm{Na}^{+}, \mathrm{Ca}^{+2}\right)$, while it increased the concentration of other cations such as $\left(\mathrm{Mg}^{2+}, \mathrm{Fe}^{2+}, \mathrm{Mn}^{2+}\right)$ in comparison with the untreated soil.

\section{Table 4}

\subsection{SPW concentrations of TE}

The most obvious feature of the studied subplots was the high level of contamination in the soil pore water by various TE such as $\mathrm{Mo}, \mathrm{Zn}, \mathrm{Cu}, \mathrm{Cr}$, As and $\mathrm{Co}$ (Fig. 1). The average concentration of TE collected from the 9 SPW extracted from the 9 potted contaminated soils showed a high effect of soil amendment on the TE concentrations in the SPW. These concentrations were often related to the total TE concentration in the soil. Their average concentrations in the treated and untreated contaminated soils (RCW, CSS and NE) were as follows: $3.32 \mathrm{mg} . \mathrm{l}^{-1}$ of MO, $2.7 .7 \mu \mathrm{g} . \mathrm{l}^{-1}$ of $\mathrm{Zn}$ 
, $41.1 \mu \mathrm{g} .1^{-1}$ of $\mathrm{Cr}, 43.0 \mu \mathrm{g} .1^{-1}$ of $\mathrm{Cu}, 15.5 \mu \mathrm{g} .1^{-1}$ of As, and $2.6 \mu \mathrm{g} .1^{-1}$ of Co (Fig. 1). The values shown on figure 1 are the median, 25\%-75\% and the Min-Max for (n=9).

Organic amendments (RCW and CSS) significantly affected the Mo soil pore water [Mo ${ }_{\mathrm{SPW}}$ ] of the treated soils compared with untreated soil $(\mathrm{P}=0.02)$. RCW added to the soil slightly decreased [Mo sPw] in the soil by $(0.4 \%)$, whereas this decrease was more significant in the soil treated with CSS (36\%) compared with the untreated soil (NE). Our results demonstrated that CSS was the best amendment to reduce [Mo $\left.{ }_{\text {SPw }}\right]$ in the contaminated soils (fig.1.a).

Figure $(1, b)$ shows that the organic amendments had two different significant effects on the mobility of $\mathrm{Zn}$ in the soil. The addition of $\mathrm{RCW}$ reduced $\mathrm{Zn}$ soil pore water concentration $\left[\mathrm{Zn}_{\text {spw }}\right]$ by about $57 \%$ compared with the untreated soil (from $172.94 \pm 40.85\left(\mu \mathrm{g} .1^{-1}\right)$ in the soil (NE) to $72.79 \pm 27.31\left(\mu \mathrm{g} .1^{-1}\right)$ in the soil treated with RCW). In contrast the CSS had an inverse effect on Zn mobility, increasing the concentration of mobile $\mathrm{Zn}$ compared to the untreated soil by $54 \%$ (from $172.94 \pm 40.85\left(\mu \mathrm{g} . \mathrm{l}^{-1}\right)$ in the soil (NE) to $377.40 \pm 33.78\left(\mu \mathrm{g} . \mathrm{l}^{-1}\right)$ in the soil treated with CSS). A very significant correlation $(r=0.76, r=0.71)$ was observed between the DOC and the TOC and the SPW zinc concentration in the soil solution $\left[\mathrm{Zn}_{\mathrm{spw}}\right]$ respectively.

Figure $(1, \mathrm{c})$ shows the effect of organic amendments on the $\mathrm{Cu}$ soil pore water concentration $\left[\mathrm{Cu}_{\mathrm{spw}}\right]$. Organic amendments had a significant effect on the mobility of $\mathrm{Cu}$ in the soil $(\mathrm{p}=0.000001)$. $\mathrm{RCW}$ reduced $[\mathrm{Cu}$ spw by 4 fold compared with the untreated soil (NE), from $18.05 \pm 0.89\left(\mu \mathrm{g} .1^{-1}\right)$ in the soil $(\mathrm{NE})$, to $4.59 \pm 0.86\left(\mu \mathrm{g} . \mathrm{l}^{-1}\right)$ in the soil treated with $\mathrm{RCW}$, whereas CSS increased the mobile $\mathrm{Cu}$ concentration by 6 fold compared with the soil without amendment, from $18.05 \pm 0.89\left(\mu \mathrm{g} . \mathrm{L}^{-1}\right)$ in the soil $(\mathrm{NE})$, to $106.45 \pm 21.15\left(\mu \mathrm{g} . \mathrm{l}^{-1}\right)$ in the soil treated with (CSS). Additionally we found that total $\mathrm{Cu}$ concentration measured in the SPW $\left[\mathrm{Cu}_{\mathrm{spw}}\right]$ was highly related to the total organic matter content of the soils $\left([\mathrm{Cu} \operatorname{sPw}]\left(\mu \mathrm{g} .1^{-1}\right)=-48.72+43.669 * \mathrm{TOC}(\%)\right.$, Correlation: $\left.\mathrm{r}=0.8321\right)$, and dissolved organic matter of the SPW $\left(\left[\mathrm{Cu}_{\mathrm{SPW}}\right]\left(\mu \mathrm{g} . \mathrm{l}^{-1}\right)=-39.57+2.2615 *\right.$ DOC $\left(\mathrm{mg} \cdot \mathrm{l}^{-1}\right)$, Correlation: $\left.\mathrm{r}=0.91562\right)$.

The effect of organic amendments (CSS and RCW) on the mobility of $\mathrm{Cr}$ in the soil can be clearly observed in figure $(1, \mathrm{~d})$. The organic amendments significantly reduced the $\mathrm{Cr}$ soil pore water concentration $\left[\mathrm{Cr}_{\mathrm{spw}}\right]$ in the treated soil by nearly 1.7 fold compared with the untreated soil $(\mathrm{p}=0.00006)$. This reduction was $39 \%$ for the soil amended with RCW (from 56.02 $\pm 9.86\left(\mu \mathrm{g} .1^{-1}\right)$ in the soil NE to $34.97 \pm 7.59\left(\mu \mathrm{g} .1^{-1}\right)$ in the RCW soil), and $42 \%$ for the soil amended with CSS (from 56.02 $\pm 9.86\left(\mu \mathrm{g} . \mathrm{l}^{-1}\right)$ in the soil NE to $32.48 \pm 8.27\left(\mu \mathrm{g} .1^{-1}\right)$ in the CSS soil). A good correlation was 
observed between the soil $\mathrm{pH}$ and the $\left[\mathrm{Cr}_{\mathrm{spw}}\right](\mathrm{r}=0.68)$, whereas DOC and TOC values were significantly negatively correlated with the Cr SPW concentration $(r=-0.716 . \mathrm{p}=<0.05$ and $\mathrm{r}=-0.714, \mathrm{p}=<0.05$ respectively $)$.

Figure $(1, \mathrm{e})$ shows the different effects of organic amendments on the As soil pore water concentration $\left[\mathrm{As}_{\mathrm{spw}}\right]$. The addition of RCW to the soil did not have any effect on the $\left[\mathrm{As}_{\mathrm{spw}}\right]$ concentration $11.72 \pm 3.41\left(\mu \mathrm{g} .1^{-1}\right)$ compared with the untreated soil $\left(11.63 \pm 3.96\left(\mu \mathrm{g} .1^{-1}\right)\right.$, whereas the effect of CSS on the As concentration in the SPW compared to the soil treated with RCW and NE soils was significant ( $\mathrm{p}=0.000004)$. Soil amended with CSS increased the As mobility by 49.4\% compared with the RCW soil and by $50.2 \%$ compared with the NE soil: As concentration increased from $\left(11.63 \pm 3.96\left(\mu \mathrm{g} .1^{-1}\right)\right.$ of $\left[\mathrm{As}_{\mathrm{spw}}\right]$ in the NE soil to $23.32 \pm 4.51\left(\mu \mathrm{g} .1^{-1}\right)$ of $\left[\mathrm{As}_{\mathrm{spw}}\right]$ in the soil treated with CSS. A very strong correlation was observed between DOC and TOC measured in SPW and in soil and the $\left[\mathrm{As}_{\mathrm{spw}}\right]$ concentration measured in the SPW solutions; this correlation was $\mathrm{r}=0.82, \mathrm{p}=<0.05$ and $\mathrm{r}=0.80, \mathrm{p}<0.05$ respectively.

RCW and CSS added to the soil significantly affected the Co soil pore water concentration $\left[\mathrm{Co}_{\mathrm{spw}}\right]$ in the treated soil and untreated soil $\left(\mathrm{p}=1.64 \mathrm{E}^{-11}\right)$. The effect of RCW and CSS added to the soil on the mobility of Co in the soil was similar to their impact on the mobility of $\mathrm{Cu}$. Figure $(1, \mathrm{f})$ shows that the addition of RCW to the contaminated soil reduced $\left[\mathrm{Co}_{\text {spw }}\right]$ by $48 \%$ compared with the untreated soil $\mathrm{NE}$ (from $1.32 \pm 0.48\left(\mu \mathrm{g} . .^{-1}\right)$ in the (NE) soil to $0.68 \pm 0.3248$ $\left(\mu \mathrm{g} .1^{-1}\right)$ in the (RCW) soil). In contrast, CSS increased the Co mobility by $82 \%$ compared to the (NE) soil, from $1.32 \pm 0.48\left(\mu \mathrm{g} .1^{-1}\right)$ in the (NE) soil to $7.17 \pm 1.36\left(\mu \mathrm{g} .1^{-1}\right)$ in the (CSS) soil. The SPW Co concentration shows a very good correlation with both DOC and TOC; this relation was very strong with DOC values $(r=0.89, p=<0.01)$, whereas it was less strong with the TOC $(\mathrm{r}=0.79, \mathrm{p}=<0.05)$.

\section{Figure 1}

\subsection{Soil exposure intensity of TE}

Soil amendment did not have a significant effect on the soil exposure intensity of $\mathrm{Zn}$ in the treated soil compared with the soil (NE) (Table 5) for either of the organic amendments. The $\mathrm{R}$ values calculated from the [ $\mathrm{Zn}_{\text {DGT }}$ ] divided by [ $\mathrm{Zn}$ spw] measured in the untreated contaminated soil (NE) and the soil amended with CSS were lower than that 
measured in the soil amended with RCW (Table 5). The increase in the $\left(\mathrm{Zn}{ }_{\mathrm{R}}\right)$ values in the three types of soil was as follows: $\mathrm{CSS}<\mathrm{NE}<\mathrm{RCW}$, where CSS has the capacity to reduce the $\left(\mathrm{Zn}{ }_{\mathrm{R}}\right)$ values by about $60 \%$, while the soil amended by RCW increased it by $51 \%$ compared with the NE soil. The higher value in the soil amended with RCW may also indicate higher values of available $\mathrm{Zn}$ during the first hours of deployment, due to a higher initial mobilization flux from the solid phase (Zhang et al., 2001).

The untreated soil (NE) provided the highest concentration of soluble $\mathrm{Cr}\left(56.02 \pm 9.86 \mu \mathrm{g} . \mathrm{l}^{-1}\right)$ and the highest concentration of available Cr; this contribution was about $2 \%$ of the SPW concentration of Cr. RCW and CSS added to the soil decreased the available concentration of $\left[\mathrm{Cr}_{\text {DGT }}\right]$ in the contaminated soils compared with the untreated soil (NE) (Table 5). RCW decreased significantly $(\mathrm{p}=0.00001)$ the available $\mathrm{Cr}$ concentration by nearly $73 \%$, reducing the available $\mathrm{Cr}$ concentration from $0.67 \pm 0.10 \mu \mathrm{g} . \mathrm{l}^{-1}$ in the soil without amendment (NE) to $0.18 \pm 0.03 \mu \mathrm{g} .1^{-1}$ in the soil treated with RCW. In the soil amended with CSS, the available concentration of $\mathrm{Cr}$ was slightly reduced by $9 \%$ compared with the control soil. The available concentrations of $\mathrm{Cr}$ in the soil amended with CSS and in the soil without amendment NE were about $1.9 \%$ and $0.5 \%$ of the SPW concentration of $\mathrm{Cr}$ in these soils. Table 5 also presents the [Cr DGT $]$ : [Cr $\left.{ }_{\text {spw }}\right]$ ratio $\mathrm{R}\left(\mathrm{Cr}_{\mathrm{R}}\right)$ values for all contaminated and uncontaminated soils. The soil amended with $\mathrm{RCW}$ presented $\left(\mathrm{Cr}_{\mathrm{R}}\right)$ values 56\% lower than that in the NE soil, whereas the soil amended with CSS had the highest $\left(\mathrm{Cr}_{\mathrm{R}}\right)$ values (about 3.8 and 1.7 fold more than that in the RCW and NE soils respectively).

A strong negative correlation was observed between $\left[\mathrm{Cr}_{\mathrm{spw}}\right]$ and total and dissolved organic matter in the soil and solution $\mathrm{r}=-0.82, \mathrm{r}=-0.87$ respectively, and between $\left[\mathrm{Cr}_{\text {DGT }}\right]$ and the electrical conductivity $(\mathrm{EC})$ in the soil $\mathrm{r}=-0.89$. $\left[\mathrm{Cr}_{\text {DGT }}\right]$ also showed a good correlation with total $\mathrm{Cr}$ in the soil $\mathrm{r}=0.68$.

We did not detect any available concentration of $\mathrm{Cu}$ and $\mathrm{Co}$ in the DGT used, thus the ratio calculated from the mobile and available fraction was equal to zero (Table 5).

Table 5 


\subsection{Biomass of primary BL and TE phytoavailability}

Table 6 shows the DW and foliar TE concentration of the BL grown on treated and untreated contaminated soils. The bean leaf dry weight (BLDW) in the soil amended with CSS was equal to that of the untreated contaminated soil, whereas the soil amended with RCW increased the BLDW by $14 \%$ and $15 \%$ compared to the CSS and NE soils respectively $(\mathrm{p}=0.013)$. TE phytoavailability was assessed by measuring TE concentrations in the primary BL. The results presented in Table 6 also show that RCW and CSS added to the contaminated soil significantly decreased the concentration of Mo, Cr, As and Co measured in the BL compared with the soil without amendment (NE) $(\mathrm{p}<0.0001)$. This decrease S was about 2.4 and 1.6 fold for Mo, 6 and 3.8 fold for $\mathrm{Cr}, 2$ and 1.8 fold for As and 1.5 and 1.2 fold for Co respectively (e.g. Cr concentration decreased from $14.46 \pm 1.06\left(\mathrm{mg}_{\mathrm{kg}}{ }^{-1}\right)$ in the NE soil to $2.35 \pm 0.11\left(\mathrm{mg} \cdot \mathrm{kg}^{-1}\right)$ in the $\mathrm{RCW}$ soil and to $3.82 \pm 0.52\left(\mathrm{mg} \cdot \mathrm{kg}^{-1}\right)$ in the CSS soil). In contrast the $\mathrm{Cu}$ concentration in the BL increased after the addition of RCW and CSS to the soil, but this effect was not significant compared with the untreated soil as this increase was about $10 \%$ and $6 \%$ respectively (from $14.56 \pm 0.21\left(\mathrm{mg} \cdot \mathrm{kg}^{-1}\right)$ in the NE soil to $16.17 \pm 1.28\left(\mathrm{mg}^{\mathrm{kg}} \mathrm{kg}^{-1}\right)$ in the soil amended with CSS). Additionally the effect of RCW and CSS on Zn concentration in the BL was different from the other TE. RCW reduced the Zn concentration in the BL slightly by $7 \%$ whereas the addition of CSS increased the $\mathrm{Zn}$ concentration slightly by $6.5 \%$ compared to the untreated soil. A good correlation was found between the foliar Mo, As and $\mathrm{Cr}$ concentration and the soil $\mathrm{pH}$ measured in these soils $(\mathrm{r} \geq 0.7$ and $\mathrm{p}<0.05)$.

\section{Table 6}

Figure 2 shows the mineral masses of $\mathrm{Mo}, \mathrm{Zn}, \mathrm{Cu}, \mathrm{Cr}, \mathrm{As}$ and $\mathrm{Co}$ in the primary BL $\left(\mu \mathrm{g} \cdot\right.$ plant $\left.^{-1}\right)$ calculated based on the foliar element concentration $\left(\mu \mathrm{g} \cdot \mathrm{kg}^{-1} \mathrm{DW}\right)$ and leaf biomass production $\left(\mu \mathrm{g} \mathrm{DW} . \mathrm{pot}^{-1}\right)$. A higher significant decrease $(\mathrm{p}<0.0001)$ was found in the mineral masses of the Mo, $\mathrm{Cr}$ and As metals in the treated soils (RCW and CSS) compared with the untreated (NE) soil. This decrease in the Mo, $\mathrm{Cr}$ and As mineral masses in plants after the addition of RCW and CSS was as follows: 2.0 and 1.6 fold for Mo , 5.2 and 3.8 fold for Cr and 1.7, and 1.8 fold for As respectively. Organic amendments slightly decreased the Co mineral mass by 1.3 and 1.2 fold after the addition of RCW and CSS respectively. However the amendment effects were not significant compared to the other TE. In contrast the effect of soil amendment on the $\mathrm{Cu}$ and $\mathrm{Zn}$ mineral masses was different: the addition of RCW and CSS increased 
the mineral mass of $\mathrm{Cu}$ by $22 \%$ and $4 \%$ and by $8 \%$ and $6 \%$ for the $\mathrm{Zn}$ respectively compared with the untreated soil (NE).

If only the effects of organic amendments on the mineral masses of TE are compared, we can see that the soil amended with RCW was more able than CSS to reduce the mineral mass of Mo, $\mathrm{Cr}$ and $\mathrm{Co}$ in the BL tissues. The RCW decreased the mineral mass of these TE in the BLDW by $19 \%$ for Mo, $27 \%$ for $\mathrm{Cr}$ and $10 \%$ for Co compared with that calculated in the soil amended with CSS. In contrast RCW was more efficient than CSS at increasing the mineral masses of $\mathrm{Zn}, \mathrm{Cu}$ and $\mathrm{As}$ by $2 \%, 18$ and $5 \%$ respectively. A strong positive correlation was in fact found between the mineral masses of $\mathrm{Mo}, \mathrm{Cr}$, and $\mathrm{As}$ except $\mathrm{Cu}$ and the soil $\mathrm{pH}(\mathrm{r}>0.7, \mathrm{p}<0.05)$, whereas this correlation was strongly negative between the same TE mineral masses and the EC measured of the SPW $r>0.8, p=<0.001$ and $r=0.80, p<0.05$ respectively.

\section{Figure 2}

\section{Discussion}

\subsection{Mobility of TE}

All our results showed that RCW added to the contaminated soil decreased the mobile fraction of TE (Mo, Zn, $\mathrm{Cu}, \mathrm{Cr}$ and $\mathrm{Co}$ ) in the SPW compared with the untreated soil (Table 4).

Munksgaard and Lottermoser (2010) tested the effect of two amendments on metal mobility in metalcontaminated soils from the Broken Hill mining center, Australia. The first amendment was Phosphate fertilizer (bovine bone meal, superphosphate, triple superphosphate, potassium orthophosphate) and the second was a fresh organic amendment (pine bark (Pinus radiata)). The two amendments were applied to two soils contaminated with mining waste. The results showed that the addition of fertilizers and/or pine bark to both soil types increased water extractable metals and metalloids concentrations ( $\mathrm{As}, \mathrm{Cd}, \mathrm{Cu}, \mathrm{Fe}, \mathrm{Mn}, \mathrm{Pb}, \mathrm{Sb}, \mathrm{Zn}$ ) compared with unamended soils. Composted organic waste amendments such as composted sewage sludge have been shown to have multiple benefits of improving vegetation establishment, reducing compaction, (Bernal et al., 2006), protecting against erosion (Craul, 1999; Whalen et al., 2003) and binding metals (Song and Greenway, 2004). The rapid mobilization and vertical transport of trace metals and As was also a consequence of adding this material to the soil (Beesley and Dickinson, 2010; Beesley et al., 2010). 
Clemente et al. (2006) reported that fresh organic waste, such as municipal waste compost (MWC), is rich in soluble organic compounds which can increase the mobility of $\mathrm{Zn}$ by $48 \%$ and of $\mathrm{Cu}$ by $74 \%$ compared with the control soil shortly after the addition of these materials to soil, and that this increase results from the formation of soluble organometallic complexes. These results are confirmed by our finding that the addition of CSS to the soil increased the mobile fraction of $\mathrm{Zn}$ by 54\% compared with the untreated soil. Smith (2009) reported that the addition of compost and sewage sludge to agricultural and other soils raises the soil content and the availability of heavy metals for transfer into crop plants. The availability in soil depends on the nature of the chemical association between a metal and the organic residual and soil matrix, the $\mathrm{pH}$ value of the soil, the concentration of the element in the compost and the soil, and the ability of the plant to regulate the uptake of a particular element. There is no evidence of increased metal release in available forms as organic matter degrades in soil once compost applications have ceased. This is confirmed by our results (Table 4) and may explain the increase in the mobile $\mathrm{Zn}(54 \%), \mathrm{Cu}(83 \%)$, Co (82\%) and As (49\%) concentrations in the SPW after the addition of CSS to the contaminated soil compared with the untreated one. Additionally we noticed that the mobility of TE was strongly related to the dissolved and total organic carbon concentrations measured in the soil and soil solution. Moreover, the composition of organic amendments can change with time due to the decomposition of organic matter by soil microorganisms, with soluble organo-metal complexes being released into soil solution (Hooda and Alloway, 1994; Kaschl et al., 2002). Xia et al. (2005) tested the effect of varying amendment rates of compost on the mobility and the leaching potential of TE in the soil. They found that increasing compost rates significantly increased the extractable fraction of $\mathrm{Cu}$ and $\mathrm{Zn}$ by 8 fold and 7 fold respectively at $1 \mathrm{~L} . \mathrm{L}^{-1}$ of compost compared with the soil without compost $\left(0 \mathrm{~L} . \mathrm{L}^{-1}\right)$. This is confirmed by the present study where we found that $\mathrm{CSS}$ added to contaminated soil increased the mobile fraction of $\mathrm{Cu}$ and $\mathrm{Zn}$ by 6 and 2.2 fold respectively compared with the soil without amendment. Beesley et al. $(2010,2014)$ found that applying amendments such as compost and biochar amendments to multi-element contaminated soils can have contradictory effects on the mobility, bioavailability and toxicity of specific elements, depending on the amendment. TE were measured after 60 days in a contaminated soil amended with biochar and green waste compost, after phytotoxicity had been assessed by a simple bio-indicator test. They found that $\mathrm{Cu}$ and As concentrations in the SPW increased more than 30 fold after adding both amendments, associated with significant increases in dissolved organic carbon and $\mathrm{pH}$, whereas $\mathrm{Zn}$ and $\mathrm{Cd}$ significantly decreased. Gigliotti et al. (1996) measured the accumulation of TE in the top $20 \mathrm{~cm}$ of calcareous soil amended with urban waste compost. They reported that compared with untreated soils, amended soils showed a significant increase 
only in $\mathrm{Cu}, \mathrm{Zn}, \mathrm{Pb}$ and, in the last 2 years, $\mathrm{Cr}$ concentrations. They concluded that the long-term application of large amounts of urban waste compost to $\mathrm{CaCO}_{3}$-containing soils does not necessarily cause medium-term problems to plant, animal or human health. Two types of composts were tested as mulching materials in a vineyard by Pinamonti, (1998): one was sewage sludge and bark (SB) compost with a low trace element concentration, the other was a municipal solid waste (MSW) compost with a higher concentration of metals. Both compost mulches ameliorated soil properties; they increased organic matter content and improved the porosity and water retention capacity of the soil. The SB compost only caused a significant increase in total and DTPA-extractable $\mathrm{Zn}$ in the soil; with this compost the soil concentrations of the other trace elements examined $(\mathrm{Cu}, \mathrm{Ni}, \mathrm{Pb}, \mathrm{Cd}$ and $\mathrm{Cr})$ did not show any significant changes. In contrast, the MSW compost, used over a six-year period, increased concentrations of total $\mathrm{Zn}, \mathrm{Ni}, \mathrm{Pb}, \mathrm{Cd}$ and $\mathrm{Cr}$ and of DTPA extractable $\mathrm{Zn}, \mathrm{Ni}, \mathrm{Pb}$ and $\mathrm{Cd}$ in the soil when compared to the control. Cao et al. (2003) investigated the effects of phosphate rock, municipal solid waste and Biosolids (BS) on the leaching of As from soils and As uptake by Chinese brake fern in a chromated-copper-arsenate (CCA) contaminated soil or in As spiked contaminated (ASC) soil. They found that As uptake in the compost-treated CCA soil was related to the increase of soil water-soluble As and As(V) transformation into As(III). Reduced As uptake in the ASC soil may be attributed to As adsorption to the compost. Compost and phosphate amendments increased As leaching from the CCA soil by $34 \%$ and $26 \%$ compared with the control soil, but decreased leaching with the presence of an As accumulator (Chinese brake fern (Pteris vittata L)). These results confirm the effect of CSS which increased the mobile concentration of As by $49 \%$ compared with the untreated soil. The ecological effects of metals and metalloids in soils are closely related to the concentration and speciation of the elements in the soil and soil pore water (Bruemmer et al., 1986). Generally the plant exposure to metals is related to the concentrations of both mobile and available trace metals in SPW (Sauvé et al., 1997; Sauvé, 2003; Tandy et al., 2006; Forsberg et al., 2009; Hattab et al., 2014b). Organic matter additions to soil have long been considered important in maintaining the quality of both natural and managed soils. When RCW decomposes on a soil, stable and enduring humus is created. The lignins in the RCW are slowly broken down by naturally occurring fungi, and these fungi also play a vital role in the soil food web, serving as nourishment for microorganisms (bacteria, fungi, and soil fauna), which rapidly invade the RCW according to specific stages of succession (Käärik, 1974). The second organic matter which we used, composted sewage sludge (CSS), provides more mature soil organic matter than RCW. 
The majority of trials showed higher SOM effects on soil properties especially with composted material. Whatever the carbon source (straw, manure, compost), it has a significant impact on soil properties. However, well matured compost leads to a higher SOM increase than fresh compost. The stable $\mathrm{C}$ fraction responsible for OM reproduction is higher in mature compost (50\% of total compost $\mathrm{C}$ ). This increase in soil organic matter results from the increase in the amount of organic matter and the biological activity present within the soil due to the fresh pool of organic substrate. SOM has probably the greatest capacity and strength of bonding with most trace metals of any soil component (the possible exceptions are some non-crystalline minerals with very high surface areas). As a result, there are often statistically significant correlations between solubility of trace metals such as $\mathrm{Cu}, \mathrm{Hg}$ and $\mathrm{Cd}$, and soil organic matter content. Generally the metals that bond most strongly to SOM tend also to be the most rapidly adsorbed. When these metals such as $\mathrm{Pb}^{3+}, \mathrm{Cd}^{2+}, \mathrm{Cu}^{2+}$ and $\mathrm{Fe}^{3+}$ form complexes with soil organic matter their lability decreases. In contrast when some trace elements such as $\mathrm{Cu}^{2+}, \mathrm{Ni}^{2+}$ and $\mathrm{Co}^{2+}$ form acid-metal complexes with dissolved humic and fulvic acid, they appear to be largely labile. This lability is controlled by the soil $\mathrm{pH}$ and the metal/organic ratio, which decreases with increasing $\mathrm{pH}$ and with decreasing metal/organic ratio (Petruzzelli and Pezzarossa, 2003; Leita et al., 2003; Sherene, 2010).

\subsection{Phytoavailability of TE}

Organic amendments added to the soil (RCW and CSS) reduced Mo, Cr, As and Co concentrations in the beans grown in treated soil compared to the untreated soil. The concentrations of many TE exceeded the limit values reported by (Kabata-Pendias and Pendias, 2000) for foliar $\mathrm{Cu}, \mathrm{Cr}$, As and $\mathrm{Zn}$, i.e. 20, 5, 5 and $100 \mathrm{mg} . \mathrm{kg}^{-1} \mathrm{DW}$ respectively, and those reported by MacNicol and Beckett (1985), namely 15-30 $\mu \mathrm{g} \mathrm{Cu} \mathrm{g}^{-1} \mathrm{DW},<1 \mu \mathrm{g} \mathrm{Cr} \mathrm{g}^{-1} \mathrm{DW}, 60-250 \mu \mathrm{g} \mathrm{Zn} \mathrm{g-}{ }^{-1} \mathrm{DW}$ and 1-4 $\mu$ g As g- ${ }^{-1}$ DW.

The addition of fresh organic material (RCW) to the soil decreased the mobility of $\mathrm{Zn}, \mathrm{Cr}, \mathrm{Cu}$ and Co measured in the soil solutions (Fig. 1) and the TE concentrations of (Mo, Cr, Zn, As and Co) measured in the BL, except for Cu (Table 5). Angelova et al. (2010) investigated the effect of several organic amendments (peat, compost and vermin compost) on the quantity of mobile forms of $\mathrm{Pb}, \mathrm{Zn}, \mathrm{Cd}$ and $\mathrm{Cu}$ and the uptake of these elements by potato (Solanum tuberosum $\mathrm{L}$.) plants. They concluded that the application of soil amendments favors plant growth and its development which is confirmed by our results in the case of CSS whereas RCW showed no effect; these effects were best expressed with the application of $10 \%$ compost (5\% in our experience). They also found that organic amendment application led to an 
effective immobilization of $\mathrm{Pb}, \mathrm{Cu}, \mathrm{Zn}$ and $\mathrm{Cd}$ phytoavailable forms in soil and decreased the trace metal content in the potato peel and tubers. This agrees with what we found after $\mathrm{RCW}$ addition except for $\mathrm{Cu}$, and except for $\mathrm{Cu}$ and $\mathrm{Zn}$ after CSS addition. Gigliotti et al. (1996) investigated the effects of soil amended with urban waste compost on the uptake and distribution of $\mathrm{TE}(\mathrm{Cd}, \mathrm{Cu}, \mathrm{Ni}, \mathrm{Pb}, \mathrm{Zn}$ and $\mathrm{Cr})$ in corn plants grown in this soil. They reported that the corn plants grown on the amended soil showed a general increase in metal uptake, which was about three times greater for $\mathrm{Pb}$ and two times greater for the other metals than in plants grown on untreated soil. They also found $\mathrm{Cu}$ and $\mathrm{Zn}$ in all plant parts and although the quantity absorbed by the plants from the treated plots was higher, their distribution was uniform in all plants. These results agree with the effect of CSS added to our soil concerning $\mathrm{Cu}$ and $\mathrm{Zn}$ concentration in the bean leaves, which increased by about 6 and $6.5 \%$ compared with the control soil. Businelli et al. (1996) investigated the effect of two types of compost (MWC) on the mobility and the availability of $(\mathrm{Cu}, \mathrm{Pb}, \mathrm{Zn}, \mathrm{Cd}, \mathrm{Cr}$ and $\mathrm{Ni}$ ) in an argillaceous loam calcareous soil for 6 years. They found that amendments significantly increased the mobile TE concentrations in the treated soil compared with the untreated one. $\mathrm{Cu}, \mathrm{Pb}$, and $\mathrm{Zn}$ concentrations measured in the plants grown on the amended soil were generally higher than those measured in the control soil. This was not however the case for $\mathrm{Cd}, \mathrm{Cr}$ and $\mathrm{Ni}$ measured in the treated soil. Our results fully confirm these findings on the effects of CSS, which increased Cu and $\mathrm{Zn}$ concentration in the BL, whereas it decreased the Cr concentration by 3.8 fold compared with the untreated soil. Bes and Mench (2008) added five types of organic matter (three phosphate compounds, zerovalent iron grit (ZVIG, $2 \%$ by soil weight), two alkaline compounds, and two commercial formulations) singly and some combined with ZVIG, to a highly $\mathrm{Cu}-$ contaminated topsoil $\left(2600 \mathrm{mg} \mathrm{Cu} \mathrm{kg}^{-1}\right)$ from a wood treatment facility. They found that the majority of amendments enhanced the growth of beans in treated soils compared to the untreated one. They also reported that CSS and Compost poultry manure (CPM) added to the contaminated soil increased the quantity of the biomasses by about 1.5 fold and 1.4 fold respectively compared with the untreated soil. In our experiment CSS did not have any effect on the biomass of the BL compared with the untreated soil, whereas RWC increased the BL biomass slightly by 1.2 fold compared with the untreated soil. $\mathrm{Cu}$ and $\mathrm{Zn}$ concentrations measured in the BL decreased by 1.5 and 2 fold respectively, while we found that the addition of CSS to our contaminated soil increased the concentration of $\mathrm{Cu}$ and $\mathrm{Zn}$ by 6 and 6.5 fold compared with the untreated soil. However the soil type and $\mathrm{Cu}$ concentration range used by Bes and Mench were very different from our study. Bes and Mench (2008) reported that the $\mathrm{Cu}$ mineral mass $\left[\mathrm{Cu}_{\mathrm{MM}}\right]$ increased in the soil amended with CSS and a mixture of Compost poultry manure and zerovalent iron grit (CPMX ZVIG), whereas our results showed that there was no significant effect of amendment on the mineral masses of $\mathrm{Cu}$ in the bean leaves. Castaldi and Melis (2004) 
reported that organic amendments (compost) contain a high proportion of humified organic matter, which could decrease the TE bioavailability in soil, thus reducing its toxicity for vegetation. The addition of fresh organic material is usually associated with the arrival of a large number of microorganisms and macroorganisms in the soil. Interactions between microorganisms and metals are multiple: accumulation, intracellular, metal/ cell wall combination, extracellular polymeric / metal interaction, etc. These reactions can lead in theory to immobilization or remobilization of the trace elements in the soil under certain environmental conditions (Ford and Mitchell, 1993). The bacteria in soil possess surfaces that interact strongly with metal ions in soil solution, which could adsorb a greater amount of heavy metals than inorganic soil components such as montmorillonite, kaolinite or vermiculite (Ledin et al., 1996), since bacterial cells (approximately $1.0 \mathrm{e} 1.5 \mathrm{~mm} 3$ ) have an extremely high ratio of surface area to volume, which endows bacteria with a strong for adsorbing and immobilizing toxic ions from soil solution (Beveridge and Schultze-Lam, 1995).

\section{Conclusion}

First, the mobility of TE was assessed by investigating the total dissolved concentrations of TE in the SPW of the amended and control soils. Total dissolved TE concentrations were determined in soil pore water (SPW) sampled by Rhizon samplers. The average results of each of the 3 plots showed that RCW significantly reduced the $\mathrm{Mo}, \mathrm{Zn}, \mathrm{Cu}, \mathrm{Cr}$ and Co dissolved concentrations in the SPW whereas it did not have any effect on the As concentration. In contrast the application of CSS significantly increased the dissolved concentrations of $\mathrm{Zn}, \mathrm{Cu}, \mathrm{Co}$ and $\mathrm{As}$ in the SPW while it decreased the concentrations of Mo and Cr. Thus RCW decreased the mobility of all the studied TE in the SPW, whereas CSS reduced the mobility of $\mathrm{Mo}, \mathrm{Cr}$ and $\mathrm{Co}$, while it increased the mobility of $\mathrm{Zn}, \mathrm{Cu}$ and As. Second, the soil exposure intensity was assessed by DGT probes. The Zn soil exposure intensity assessed by DGT was not significantly changed by the addition of RCW and CSS, while the Cr soil exposure intensity significantly decreased after RCW addition compared with the soil treated with CSS and the NE soil. Cu and Co could not be detected by DGT in our three soils, suggesting that these TE were non labile. Third, the TE phytoavailability was characterized by growing dwarf beans on potted soils and analyzing their foliar TE concentrations. The effect of organic amendments on the TE concentration in the bean leaves was very marked: we found that the soil amended with RCW provided a bean leaf dry weight higher than that of the other soils and that $\mathrm{RCW}$ was able to reduce $\mathrm{Mo}, \mathrm{Zn}, \mathrm{Cr}$, As and Co concentration in the bean leaves compared with the NE soil. RCW was also more efficient than CSS at reducing the mineral mass of $\mathrm{Mo}, \mathrm{Cr}$ and $\mathrm{Co}$ in the bean leaf tissues. In contrast, CSS was more able than RCW to increase the mineral masses of $\mathrm{Zn}$ and $\mathrm{Cu}$ 
in the bean leaves. Consequently, RCW was more effective than CSS at reducing TE mobility and phytoavailability in the contaminated technosols.

\section{Acknowledgements}

The authors gratefully acknowledge the Agence de l'Environnement et de la Maîtrise de l'Energie (ADEME), Dept. Polluted Sites \& Soils, Angers, France for its financial support (“Physafimm” program).

\section{References}

Ahmad, H.R., Ghafoor, A., Corwin, D.L., Aziz, M.A., Saifullah, S.M., 2011. Organic and inorganic amendments affect soil concentration and accumulation of cadmium and lead in wheat in calcareous alkaline soils. Commun Soil Sci Plant Anal 42:111-122.

Alloway, B.J., 1995. Heavy Metals in Soils (2nd ed.), Blackie Academic Professional, London, U.K.

Angelova, V. R., V. I. Akova, N. S. Artinova., K. I. Ivanov., 2013. The effect of organic amendments on soil chemical characteristics. Bulg. J. Agric. Sci., 19: 958-971

Angelova, V.A., Radka Ivanova, B., Galina Pevicharova, C., Krasimir, I., 2010. Effect of organic amendments on heavy metals uptake by potato plants. In: 19th World congress of soil science, soil solutions for a changing world, 1-6 August 2010, Brisbane, Australia. Published on DVDBaize, 2000. Teneurs totales en « métaux lourds »dans les sols français. Résultats généraux du programme Aspitet. Le Courrier de l'environnement de 1'INRA, 39, 39-54.

Basta, N.T., McGowen, S.L., 2004. Evaluation of chemical immobilization treatments for reducing heavy metal transport in a smelter contaminated soil. Environ Pollut. 127: 73- 82.

Beesley, L., Dickinson, N.M., 2010. Carbon and trace element mobility in an urban soil amended with green waste compost. Journal of Soils and Sediments 10, 215e222.

Beesley, L., Inneh, O.S., Norton, G.J., Jimenez, E.M., Pardo, T., Clemente, R., Dawson, J.J.C., 2014. Assessing the influence of compost and biochar amendments on the mobility and toxicity of metals and arsenic in a naturally contaminated mine soil. Environ. Pollut. 186, 195-202

Beesley, L., Moreno-Jimenez, E., Gomez-Eyles, J. L., 2010. Effects of biochar and greenwaste compost amendments on mobility, bioavailability and toxicity of inorganic and organic contaminants in a multi-element polluted soil. Environ. Pollut., 158, 2282-2287.

Bernal, M.P., Clemente, R., Walker, D.J., 2006. The role of organic amendment in the bioremediation of heavy metal polluted soils. In: Gore, R.W. (Ed.), Environmental Research at the Leading Edge. Nova Science, pp. 1e60. 
Bes, C., Mench, M., 2008. Remediation of copper-contaminated topsoils from a wood treatment facility using in situ stabilisation. Environ. Pollut. 156: 1128-1138.

Beveridge, T.J., Schultze-Lam, S., 1995. Detection of anionic sites on bacterial walls, their ability to bind toxic heavy metals and form sedimentable flocs and their contribution to mineralization. In: Allen, H.E., Huang, C.P., Bailey, G.W. (Eds.), Metal Speciation and Contamination of Soil. CRC Press, Boca Raton, pp. 183-205.

Bolan, N.S., Duraisamy, V.P., 2003. Role of inorganic and organic soil amendments on immobilisation and phytoavailability of heavy metals: a review involving specific case studies. Australian Journal of Soil Research 41, 533-555.

Bragato, G., Leita, L., Figliolia, A., de Nobili, M., 1998. Effects of sewage sludge pre-treatment on microbial biomass and bioavailability of heavy metals. Soil \& Tillage Research 46: 129 - 134.

Branzini, A., Zubillaga, M.S., 2012. Comparative Use of Soil Organic and Inorganic Amendments in Heavy Metals Stabilization. Applied and Environmental Soil Science 2012, 7 pages.

Brown, S., Chaney, R., Hallfrisch, J., Ryan, J.A., Berti, W.R., 2004. In situ treatments to reduce the phyto and bioavailability of lead, zinc and cadmium. Journal of Environmental Quality 33: 522-531.

Bruemmer, G. W., Gerth, J., Herms, U., 1986. Heavy metal species, mobility and availability in soils. J. Plant Nutr. Soil Sc., 149, (4), 382-398

Bulgariu, L., Bulgariu, D., Robu, B., Macovenu, M., 2007. The impact of urbane soils pollution with heavy metals (cadmium and lead) - case study: industrial zone. Iasi city, Annals of West University of Timisoara, series Chemistry.

Businelli, M., Gigliotti, G., Guisquiani, P.L., 1996. Trace element fate in soil profile and corn plant after massive applications of urban waste compost: a six -year study. Agrochimica Vol. XL - N.4: 145 -152

Cao, X., Ma, L.Q., Shiralipour, A., 2003. Effects of compost and phosphate amendments on arsenic mobility in soils and arsenic uptake by the hyperaccumulator, Pteris vittata L. Environ Pollut 2003; 126:157- 67.

Castaldi, P., Melis,P., 2004. Growth and yield characteristics and heavy metals content on tomatoes in different growing media. Communications in Soil Science and Plant Analysis, vol. 35, no. 1-2, pp. 85-98, 2004.

Cattani, I., Fragoulis, G., Boccelli, R. E., Capri, E., 2006. Copper bioavailability in the rhizosphere of maize (Zea mays L.) grown in two Italian soils. Chemosphere 64: 1972-1979.

Chen, H.M., Zheng, C.R., Tu, C., Shen, Z.G., 2000a. Chemical methods and phytoremediation of soil contaminated with heavy metals. Chemosphere 41: 229-23

Chen, Z. S., Lee, G. J., Liu, J. C., 2000b. The effects of chemical remediation treatments on the extractability and speciation of cadmium and lead contaminated soils. Chemosphere 41:235-242.

Chen, M., Ma, L.Q., Harris, W.G., 1999. Baseline concentrations of 15 trace metals in Florida surface soils. J Environ Qual 1999;28:1173-81.

Clemente, R., Escolar, Á., Bernal, M.P., 2006. Heavy metal fractionation and organic matter mineralisation in contaminated calcareous soil amended with organic materials. Bioresour Technol 2006;97:1894-901.

Craul, P.J., 1999. Urban Soils: Applications and Practices. Wiley, London. 
Dermont, G., Bergeron, M., Mercier, G., Richer Lafleche, M., 2008. Soil washing for metal removal: A review of physical/chemical technologies and field applications. Journal of Hazardous Materials. 152 (1): 1--31

Davison, W., Fones, G., Harper, M., Teasdale, P., Zhang, H., 2000. Dialysis, DET and DGT: in Situ Diffusional Techniques for Studying Water, Sediments and Soils. In: Buffle, J., Horvai, G. (Eds.). In Situ Chemical Analysis in Aquatic Systems, Wiley.

Espitalié, J., Deroo, G., Marquis, F., 1985a. La pyrolyse Rock-Eval et ses applications, première partie. Revue de l’Institut Français du Pétrole 40: 563-579

Espitalié, J., Deroo, G., Marquis, F., 1985b. La pyrolyse Rock-Eval et ses applications, deuxième partie. Revue de 1'Institut Français du Pétrole 40: 755-784

Ernstberger, H., Davison,W., Zhang, H., Tye, A. and Young, S., 2002. Measurement and dynamic modeling of trace metal mobilization in soils using DGTand DIFS. Env. Sci. Technol., 36, 349-354.

Florea, N., Munteanu, I., 2003. Sistemul Român de Taxonomie a Solurilor (SRTS- 2003), Ed. ESTFALIA, Bucuresti.

Ford, T., Mitchell, R., 1993. Microbial transport of toxic metals, In : R. Mitchell (Eds) Environmental Microbiology, a Wiley-Liss, Inc., Publication, pp. 83-101.

Forsberg, L.S., Kleja, D.B., Greger, M., Ledin, S., 2009. Effects of sewage sludge on solution chemistry and plant uptake of $\mathrm{Cu}$ in sulphide mine tailings at different weathering stages. Appl Geochem. 24:475-482.

Geebelen, W., Adriano, D.C., Van Der Lelie, D., Mench, M., Carleer, R., Clijsters, H., Vangronsveld, J., 2003. Selected bioavailability assays to test the efficacy of amendment-induced immobilization of lead in soils. Plant and Soil. 249. 12: 217-228.

Gigliotti, G., Businelli, D., Guisquiani, P.L., 1996. Trace metals uptake and distribution in corn plants grown on a 6year urban waste compost amended soil. Agriculture Ecosystems \& Environment, Elsevier Science B.V., $58: 199-206$

Hattab, N., M. Soubrand, R. Guégan, M. Motelica-Heino, X. Bourrat, O. Faure, J. L. Buchardon., 2014a. Effect of organic amendments on the mobility of trace elements in phytoremediated techno-soils: role of the humic substances, Environmental Science and Pollution Research, September 2014, Volume 21, Issue 17, pp 1047010480

Hattab, N., Motelica-Heino, M., Bourrat, X., Mench, M., 2014b. Mobility and phytoavailability of Cu, Cr, Zn, and As in a contaminated soil at a wood preservation site after 4 years of aided phytostabilization. Environmental Science and Pollution Research. 2014 21(17). p.10307

Hooda, P.S., Alloway, B.J., 1994. Sorption of Cd and Pb by selected temperate and semi-arid soils: effects of sludge application and ageing of sludged soils. Water Air Soil Pollut 1994;74:235-50.

ISO, 2005. Soil quality - Determination of the effects of pollutants on soil flora In Part 2: Effects of chemicals on IUSS Working Group WRB, 2006, World reference basis for soil resources 2006, World Soil Resources Reports, no. 103, FAO, Rome, 128 p. 
Jamil, M., Zeb, S., Anees, M., Roohi, A., Ahmed, I., ur Rehman, S., Rha, E.S., 2014. "Role of Bacillus licheniformis in phytoremediation of nickel contaminated soil cultivated with rice," Int J Phytoremediation, Vol. 16, No. 6, pp.554-571.

Käärik, A.A., 1974. Decomposition of wood. In : C.H. Dickinson \& G.J.F. Pugh (eds.), Biology of plant litter decomposition, Volume I, Academic Press, London, pp. 129-174.

Kabata-Pendias, A., Pendias, H., 1992. Trace Elements in Soils and Plants ( ${ }^{\text {nd }}$ Edition), CRC Press Inc., Boca Raton, Florida.

Kabata-Pendias, A., Pendias, H., 2000. Trace Elements in Soils and Plants, third ed. CRC Press Inc., Boca Raton, USA.

Kaschl, A., Römheld, V., Chen, Y., 2002. The influence of soluble organic matter from municipal solid waste compost on trace metal leaching in calcareous soils. Sci Tot Environ 2002;291:45-57.

Kelly, J., Thornton, J., Simpson, P.R., 1996. Urban geochemistry: a study of the heavy metal content of soils in traditionally industrial and non-industrial areas of Britain, Appl. Geochem., 11, pp. 363-370.

Kumpiene J, Ore S, Renella G, Mench M, Lagerkvist A, Maurice C (2006) Assessment of zerovalent iron for stabilization of chromium, copper, and arsenic in soil. Environmental Pollution 144: 62- 69.

Kumpiene, J., Lagerkvist, A., Maurice, C., 2008. Stabilization of As, $\mathrm{Cr}, \mathrm{Cu}, \mathrm{Pb}$, and $\mathrm{Zn}$ in soil using amendments: A review. Waste Management 28:215-225.

Lafargue, E., Marquis, F., Pillot, D., 1998. Rock- Eval 6 applications in hydrocarbon exploration, production and soil contamination studies. Revue de l'Institut Français du Pétrole 53: 421-437

Ledin, M., Krantz-Rulcker, C., Allard, B., 1996. Zn, Cd and Hg accumulation by microorganisms, organic and inorganic soil components in multicompartment system. Soil Biol. Biochem. 28, 791e799.

Leita, L., Fornasier, F., Mondini, C., Cantone, P., 2003. Organic matter evolution and availability of metals during composting of MSW. In: Amlinger, F., Nortcliff, S., Weinfurtner, K., Dreher, P., 2003c.Applying Compost Benefits and Needs, Proc. of a seminar 22 - 23 November 2001, BMLFUW, European Commission, Vienna and Brussels http://ec.europa.eu/environment/waste/compost/seminar.htm

Lespagnol, G., Jean-Luc Bouchardon, J.L., 2011. PHYSAFIMM: PHYTOSTABILISATION, A METHODOLOGY APPLICABLE TO INDUSTRIAL, METALLURGICAL AND MINING DUMPS 1st REPORT.

MacNicol, R.D., Beckett, P.H.T., 1985. Critical tissue concentrations of potentially toxic elements Plant Soil, 85, pp. $107-129$

Madejón, P., De Mora, A.P., Felipe, E., Burgos, P and Cabrera, F., 2006. Soil amendments reduce trace element solubility in a contaminated soil and allow regrowth of natural vegetation. Environmental Pollution, vol. 139, no. 1 , pp. 40-52.

Mench M. J., Manceau A., Vangronsveld J., Clijsters H., and Mocquot B., 2000. Capacity of soil amendments in lowering the phytoavailability of sludge-borne zinc. Agronomie 20, 383-397.

Mench, M., Bert, V., Schwitzguébel, J.P., Lepp, N., Schröder, P., Gawronski, S., Vangronsveld, J., 2010. Successes and limitations of phytotechnologies at field scale: Outcomes, assessment and outlook from COST Action 859. J.Soils Sediments 10, 1039-1070 
Munksgaard, N. C., Lottermoser, B. G., 2010. Effects of wood bark and fertilizer amendment on trace element mobility in mine soils, Broken Hill, Australia: implications for mined land reclamation. Journal of Environmental Quality, 39, 2054-2062.

Perez de Mora, A., Ortega-Calvo, J.J., Cabrera, F., Madejon, E., 2005. Changes in enzyme activities and microbial biomass after 'in situ' remediation of a heavy metal-contaminated soil. Applied Soil Ecology 28, 125e137.

Petruzzelli, G., Pezzarossa, B., 2003. Sorption and availability dynamics of heavy metals in compost amended systems. In: Amlinger, F., Nortcliff, S., Weinfurtner, K., Dreher, P., 2003c. Applying Compost - Benefits and Needs, Proc. of a seminar 22 - 23 November 2001, BMLFUW, European Commission, Vienna and Brussels. http://ec.europa.eu/environment/waste/compost/seminar.htm

Pinamonti, F., 1998. Compost mulch effects on soil fertility, nutritional status and performance of grapevine., Nutrient Cycling in Agroecosystems, 51:239 - 248

Raicevic, S., Kaludjerovic., Radoicic, T., Zouboulis, A.I., 2005. In situ stabilization of toxic metals in polluted soils using phosphates: theoretical prediction and experimental verification. Journal of Hazardous Materials 117, 1, 41-53.

Ross, S. M. 1994. Rentention, tranformation and mobility of toxic metals in soils. Dans: Toxic metals in soil-plant systems. Editeur (Ross, S.M.). John Wiley and Sons, 63- 153.

Sauvé, S., 2003. Modelling trace element exposure and effects on plants. In Risk assessment and sustainable land management using plants in trace element-contaminated soils. Ed. M Mench, Mocquot, B.69-70, Centre INRA Bordeaux-Aquitaine, Villenave d'Ornon, France.

Sauvé, S., McBride, M B., Norvell., W. A., Hendershot, W. H., 1997. Copper solubility and speciation of in situ contaminated soils: Effects of copper level, pH and organic matter. Water Air and Soil Pollution 100,133-149.

Sauvé, S., Manna, S., Turmel, M. C., Roy, A. G., \& Courchesne, F. 2003. Solid-solution partitioning of Cd, Cu, Ni, $\mathrm{Pb}$, and $\mathrm{Zn}$ in the organic horizons of a forest soil. Environ. Sci.Technol. 37:5191-5196.

Segura, A., Ramos, J. L., 2013. Plant-bacteria interactions in the removal of pollutants. Curr. Opin. Biotechnol. 24 467-473 10.1016/j.copbio.2012.09.011

Sherene, T., 2010. Mobility and transport of heavy metals in polluted soil environment. Biological Forum-An Internation Journal, 2, 112-121, 2010

Smith, S.R., 2009. A critical review of the bioavailability and impacts of heavy metals in municipal solid waste composts compared to sewage sludge. Environment International 35, 142-156.

Song, Q.J., Greenway, G.M., 2004. A study of the elemental leachability and retention capability of compost. Journal of Environmental Monitoring 6, 31e37.

Soumaré, M.D., P.N.S. Mnkeni, M. Khouma., 2006. Effect of Ramial Chipped Wood and litter compost of casuarina equisetifolia tomato growth and soil properties in Niayes, Senegal. $N^{\circ} 201$. Groupe de coordination sur les BRF. Université de Laval. Département des Sciences des Bois et de la Forêt. Québec GIK 7P4 Québec, Canada. 15p.

Tandy S, Schulin R, Nowack B. 2006. Uptake of metals during chelant-assisted phytoextraction with EDDS related to the solubilized metal concentration. Environ Sci Technol. 40:2753-2758. 
Thornton, J., 1991. Metal contamination of soils in urban areas, In P.Bullock, P.J.Gregory (Eds.): Soils in Urban Environment, Blackwell, Oxford, pp. 47-75.

Vaca, R., Lugo, J., Martinez, R., 2011. Effects of sewage sludge and sewage sludge compost amendment on soil properties and Zea mays L. plants (heavy metals, quality and productivity)[J].Rev. Int. Contam. Ambie,2011,27(4):303-11.

Walker, D.J., Clemente, R., Bernal, M.P., 2004. Contrasting effects of manure and compost on soil pH, heavy metal availability and growth of Chenopodium album L. in a soil contaminated by pyritic mine waste. Chemosphere $57,215-224$.

Walker, D.J., Clemente, R., Roig, A., Bernal, M.P., 2003. The effect of soil amendments on heavy metal bioavailability in two contaminated Mediterranean soils. Environ Pollution 22, 303-312.

Whalen, J.K., Hu, Q., Liu, A., 2003. Compost applications increase water-stable aggregates in conventional and notillage systems. Soil Science Society of America Journal 67, 1842e1847

Xia, Y.P., He, Z.L., Stoffella, P.J., Calvert, D.V., Zhang, M.K. et al., 2005. Effect of compost amendment on heavy metals, nitrogen and phosphorus in a peat-based container medium. Pedosphere, 15(6):792 796.

Zhang, H., Zhao, F.J., Sun, B., Davison, W., McGrath, S., 2001. A new method to measure effective solution concentration predicts copper availability to plants. Environmental Science \& Technology. 35. pp. 2602-2607 


\section{$\underline{\text { Tables }}$}

Table 1: The main physico-chemical properties and total metal concentrations measured in the RCW and CSS.

\begin{tabular}{|c|c|c|}
\hline Chemical or physical property & CSS & $\mathbf{R C W}$ \\
\hline $\mathrm{C}(\%)$ & 21.07 & 58.8 \\
\hline $\mathrm{N}(\%)$ & 2.96 & 1.15 \\
\hline $\mathrm{C}: \mathrm{N}$ ratio & 7.12 & 51 \\
\hline $\mathrm{P}(\%)$ & 2.23 & 0.11 \\
\hline C:P ratio & 9.45 & 535 \\
\hline $\mathrm{K}(\%)$ & 0.54 & 0.53 \\
\hline $\mathrm{Ca}(\%)$ & 11.19 & 1.39 \\
\hline $\operatorname{Mg}(\%)$ & 0.5 & 0.12 \\
\hline $\mathrm{OM}(\%)$ & 30.9 & 78 \\
\hline $\mathrm{CEC}\left(\mathrm{cmol}(+) \mathrm{kg}^{-1}\right)$ & - & - \\
\hline $\mathrm{pH}\left(\mathrm{H}_{2} \mathrm{O}\right)$ & 8.8 & 5.2 \\
\hline Total TE concentrations & CSS & RCW \\
\hline $\mathrm{Cr}\left(\mathrm{mg} \cdot \mathrm{kg}^{-1}\right)$ & 91.3 & 13.7 \\
\hline $\operatorname{Mo}\left(\mathrm{mg} \cdot \mathrm{kg}^{-1}\right)$ & 2.3 & 0.5 \\
\hline $\mathrm{Cu}\left(\mathrm{mg} \cdot \mathrm{kg}^{-1}\right)$ & 161.1 & 14 \\
\hline $\mathrm{Zn}\left(\mathrm{mg} \cdot \mathrm{kg}^{-1}\right)$ & 360.2 & 97.6 \\
\hline As (mg.kg $\left.{ }^{-1}\right)$ & 16.8 & 2 \\
\hline
\end{tabular}


Table 2: Main pedological characteristics of the soils studied determined four months after the plots preparation. For each treatment, data are the mean of 3 measurements.

\begin{tabular}{|c|c|c|c|}
\hline \multirow{2}{*}{ Parameter } & \multicolumn{3}{|c|}{ Treatment } \\
\hline & $\mathrm{RCW}+\mathrm{NE}$ & $\mathrm{CSS}+\mathrm{NE}$ & $\mathbf{N E}$ \\
\hline Texture & sandy & sandy & sandy \\
\hline pH & $10.63 \pm 0.23$ & $10.63 \pm 0.12$ & $11.20 \pm 0.17$ \\
\hline C org $\left(\right.$ g.kg $\left.{ }^{-1}\right)$ & $22.07 \pm 5.64$ & $42.30 \pm 9.17$ & $19.92 \pm 3.00$ \\
\hline $\mathbf{N}\left(\mathrm{g}^{\mathrm{kg}} \mathrm{g}^{-1}\right)$ & $0.47 \pm 0.12$ & $2.33 \pm 0.32$ & $0.33 \pm 0.06$ \\
\hline $\mathrm{C} / \mathrm{N}$ & $47.70 \pm 5.10$ & $17.97 \pm 0.25$ & $60.00 \pm 5.96$ \\
\hline CEC $(m E q / 100 g)$ & $5.63 \pm 1.10$ & $6.77 \pm 0.15$ & $5.77 \pm 0.55$ \\
\hline $\mathrm{P}_{2} \mathrm{O5}\left({\left.\mathrm{g} . \mathrm{kg}^{-1}\right)}^{-1}\right.$ & $0.03 \pm 0.00$ & $0.25 \pm 0.04$ & $0.02 \pm 0.00$ \\
\hline $\mathrm{K}_{2} \mathrm{O}\left(\mathrm{g} \cdot \mathrm{kg}^{-1}\right)$ & $0.29 \pm 0.05$ & $0.59 \pm 0.07$ & $0.09 \pm 0.07$ \\
\hline $\mathrm{CaO}\left(\mathrm{g} \cdot \mathrm{kg}^{-1}\right)$ & $18.88 \pm 6.71$ & $20.70 \pm 1.13$ & $24.67 \pm 2.17$ \\
\hline $\operatorname{MgO}\left(g . \mathrm{kg}^{-1}\right)$ & $2.66 \pm 0.44$ & $1.29 \pm 0.09$ & $2.79 \pm 0.44$ \\
\hline $\mathrm{Na}_{2} \mathrm{O}\left(\mathrm{g} \cdot \mathrm{kg}^{-1}\right)$ & $0.08 \pm 0.07$ & $0.14 \pm 0.02$ & $0.14 \pm 0.03$ \\
\hline
\end{tabular}

Table 3: Total TE concentrations (hydrofluoric acid extraction) of the studied soils determined four months after plots preparation. For each treatment, data are the mean of 30 measurements (10 samples per plot, 3 plots per treatment).

\begin{tabular}{|c|c|c|c|}
\hline \multirow[b]{2}{*}{ 1.1 Metal } & \multicolumn{3}{|c|}{ 2.1 Treatment } \\
\hline & $\mathrm{RCW}+\mathrm{NE}$ & CSS + NE & NE \\
\hline $\mathrm{Cr}\left(\mathrm{mg} \cdot \mathrm{kg}^{-1}\right)$ & $5397 \pm 962$ & $5138 \pm 1057$ & $6286 \pm 957$ \\
\hline Mo $\left(\mathrm{mg} \cdot \mathrm{kg}^{-1}\right)$ & $545 \pm 175$ & $654 \pm 62$ & $660 \pm 141$ \\
\hline $\mathrm{Cu}\left(\mathrm{mg} \cdot \mathrm{kg}^{-1}\right)$ & $418 \pm 113$ & $401 \pm 56$ & $416 \pm 22$ \\
\hline $\mathrm{Zn}\left(\mathrm{mg} \cdot \mathrm{kg}^{-1}\right)$ & $1314 \pm 577$ & $1102 \pm 468$ & $1218 \pm 647$ \\
\hline As (mg.kg $\left.{ }^{-1}\right)$ & $80 \pm 19$ & $74 \pm 11$ & $91 \pm 14$ \\
\hline
\end{tabular}


Table 4: Physico-chemical characteristics of the soil and SPW (mean values \pm standard deviations) $(\mathrm{n}=9)$.

\begin{tabular}{l|c|ccc}
\hline & & RCW & CSS & NE \\
\hline \multirow{5}{*}{ Soil variables } & $\mathrm{pH}($ Soil $)$ & $9.08 \pm 0.07$ & $9.07 \pm 0.12$ & $9.34 \pm 0.18$ \\
& $\mathrm{EC}\left(\right.$ Soil) $\left(\mu \mathrm{S} . \mathrm{cm}^{-1}\right)$ & $566.67 \pm 49.4$ & $428.00 \pm 15.71$ & $317.33 \pm 54.86$ \\
& $\mathrm{TOC}($ Soil $)(\%)$ & $1.97 \pm 0.34$ & $3.14 \pm 0.34$ & $0.89 \pm 0.24$ \\
\hline \multirow{5}{*}{ SPWvariables } & $\mathrm{pH}$ & $8.91 \pm 0.04$ & $8.71 \pm 0.11$ & $8.53 \pm 0.27$ \\
& $\mathrm{EC}\left(\mu \mathrm{S} . \mathrm{cm}^{-1}\right)$ & $1750.33 \pm 148.75$ & $1786.66 \pm 174.17$ & $1474,66 \pm 142.71$ \\
& $\mathrm{DOC}\left(\mathrm{mg} . \mathrm{l}^{-1}\right)$ & $29.27 \pm 1.79$ & $59.93 \pm 14.14$ & $14.09 \pm 1.97$ \\
& $\mathrm{Cl}^{-}\left(\mathrm{mg} \cdot \mathrm{l}^{-1}\right)$ & $44.98 \pm 28.32$ & $47.45 \pm 6.12$ & $64.89 \pm 0.49$ \\
& $\mathrm{NO}_{3}^{-}\left(\mathrm{mg} . \mathrm{l}^{-1}\right)$ & $\mathrm{ND}$ & $185.27 \pm 24.91$ & $115.36 \pm 58.43$ \\
& $\mathrm{SO}_{4}^{-2}\left(\mathrm{mg} . \mathrm{l}^{-1}\right)$ & $94.43 \pm 50.48$ & $183.71 \pm 77.39$ & $358.01 \pm 27.00$ \\
& $\mathrm{PO}_{4}^{-3}\left(\mathrm{mg} . \mathrm{l}^{-1}\right)$ & $8.43 \pm 5.50$ & $6.62 \pm 0.63$ & $10.16 \pm 1.01$ \\
& $\mathrm{Na}^{+}\left(\mathrm{mg} . \mathrm{l}^{-1}\right)$ & $28.21 \pm 4.80$ & $26.56 \pm 3.73$ & $33.07 \pm 20.57$ \\
& $\mathrm{Mg}^{+2}\left(\mathrm{mg} . \mathrm{l}^{-1}\right)$ & $309.26 \pm 31.60$ & $234.54 \pm 24.73$ & $127.99 \pm 86.71$ \\
& $\mathrm{~K}^{+}\left(\mathrm{mg} . \mathrm{l}^{-1}\right)$ & $13.47 \pm 2.49$ & $12.91 \pm 0.63$ & $12.11 \pm 7.55$ \\
& $\mathrm{Ca}^{+2}\left(\mathrm{mg} . \mathrm{l}^{-1}\right)$ & $16.49 \pm 7.79$ & $57.06 \pm 12.13$ & $19.86 \pm 10.48$ \\
\hline
\end{tabular}

Table 5: Intensity of $\mathrm{Zn}, \mathrm{Cr}, \mathrm{Cu}$ and $\mathrm{Co}$ exposure determined by DGT and the ratios of $\mathrm{Zn}, \mathrm{Cr}, \mathrm{Cu}$ and $\mathrm{Co}$ (mean values \pm standard deviations) $(n=9)$.

\begin{tabular}{|c|c|c|c|c|c|c|c|c|}
\hline Soils & {$\left[\mathbf{Z n}_{\text {DGT }}\right]$} & {$\left[\mathbf{C r}_{\text {DGT }}\right]$} & $\begin{array}{l}{[\mathbf{C u}} \\
\text { DGT }]\end{array}$ & $\begin{array}{l}{[\mathrm{Co}} \\
\text { DGT }]\end{array}$ & $\left(\mathbf{Z n} \mathbf{n}_{\mathrm{R}}\right)$ & $\left(\mathbf{C r} r_{R}\right)$ & $\begin{array}{l}(\mathrm{Cu} \\
\mathrm{R})\end{array}$ & $\begin{array}{c}(\mathbf{C o} \\
\mathrm{R})\end{array}$ \\
\hline RCW & $\begin{array}{c}27.88 \pm 1.77 \\
\mathrm{a}\end{array}$ & $\begin{array}{c}0.18 \pm 0.03 \\
\mathrm{a}\end{array}$ & 0 & 0 & $\begin{array}{c}0.39 \pm 0.04 \\
\mathrm{a}\end{array}$ & $\begin{array}{c}0.005 \pm 0.001 \\
\mathrm{a}\end{array}$ & 0 & 0 \\
\hline CSS & $\begin{array}{c}27.31 \pm 1.46 \\
\mathrm{a} \\
\end{array}$ & $\begin{array}{c}0.60 \pm 0.00 \\
\mathrm{~b}\end{array}$ & 0 & 0 & $\begin{array}{c}0.07 \pm 0.00 \\
\mathrm{a} \\
\end{array}$ & $\begin{array}{c}0.018 \pm 0.006 \\
\mathrm{a} \\
\end{array}$ & 0 & 0 \\
\hline NE & $\begin{array}{c}26.07 \pm 1.97 \\
\mathrm{a}\end{array}$ & $\begin{array}{c}0.67 \pm 0.10 \\
\mathrm{~b}\end{array}$ & 0 & 0 & $\begin{array}{c}0.162 \pm 0.04 \\
\mathrm{~b}\end{array}$ & $\begin{array}{c}0.011 \pm 0.000 \\
\mathrm{a} \\
\end{array}$ & 0 & 0 \\
\hline ANOVA & NS & $* * *$ & - & - & $* * *$ & NS & - & - \\
\hline
\end{tabular}

*** Highly significant at $\mathrm{p}<0.0001, \mathrm{NS}$ (non-significant). 0 means that we couldn't detect any Cu or Co by the DGT. Mean values in a column followed by the same letter are not significantly different. Mean values in a column followed by a different letters are significantly different for $\alpha=0.001 \%$. 
Table 6: DW yields and TE concentrations of bean primary leaves. Values are mean \pm standard deviation $(\mathrm{n}=9)$.

\begin{tabular}{|c|c|c|c|c|c|c|c|}
\hline \multirow{2}{*}{$\begin{array}{c}\text { Sample } \\
\text { label }\end{array}$} & \multirow{2}{*}{$\begin{array}{l}\text { dry weight } \\
\text { of bean } \\
\text { leaves (mg) }\end{array}$} & \multicolumn{6}{|c|}{ Concentration of TE in the bean leaves (mg.kg $\left.{ }^{-1}\right)$} \\
\hline & & $\mathrm{Mo} \pm \mathrm{SD}$ & $\mathrm{Zn} \pm$ SD & $\mathrm{Cu} \pm \mathrm{SD}$ & $\mathrm{Cr} \pm \mathrm{SD}$ & $\mathrm{As} \pm \mathrm{SD}$ & $\mathrm{Co} \pm \mathrm{SD}$ \\
\hline RCW & $0.13 \pm 0.01 \mathrm{a}$ & $\begin{array}{c}14.59 \pm 1.02 \\
\mathrm{a}\end{array}$ & $\begin{array}{c}40.85 \pm 4.92 \\
\mathrm{a}\end{array}$ & $\begin{array}{c}16.17 \pm 1.28 \\
\mathrm{a}\end{array}$ & $\begin{array}{c}2.35 \pm 0.11 \\
\mathrm{a}\end{array}$ & $\begin{array}{c}0.26 \pm 0.04 \\
\mathrm{a}\end{array}$ & $\begin{array}{c}0.16 \pm 0.04 \\
\mathrm{a}\end{array}$ \\
\hline CSS & $0.11 \pm 0.00 \mathrm{~b}$ & $\begin{array}{c}21.23 \pm 0.81 \\
\mathrm{ab}\end{array}$ & $\begin{array}{c}47.03 \pm 2.97 \\
\mathrm{a}\end{array}$ & $\begin{array}{c}15.44 \pm 0.80 \\
\mathrm{a}\end{array}$ & $\begin{array}{c}3.82 \pm 0.52 \\
a b\end{array}$ & $\begin{array}{c}0.29 \pm 0.01 \\
\mathrm{a}\end{array}$ & $\begin{array}{c}0.21 \pm 0.1 \\
\mathrm{a}\end{array}$ \\
\hline NE & $0.11 \pm 0.00 \mathrm{~b}$ & $\begin{array}{c}34.26 \pm 3.61 \\
b\end{array}$ & $\begin{array}{c}43.98 \pm 2.34 \\
\mathrm{a}\end{array}$ & $\begin{array}{c}14.56 \pm 0.21 \\
\mathrm{a}\end{array}$ & $\begin{array}{c}14.46 \pm 1.06 \\
b\end{array}$ & $\begin{array}{c}0.52 \pm 0.03 \\
b\end{array}$ & $\begin{array}{c}0.24 \pm 0.5 \\
\mathrm{a}\end{array}$ \\
\hline ANOVA & $*$ & $* * *$ & NS & NS & $* * *$ & $* * *$ & NS \\
\hline
\end{tabular}

$*$ Significant at $\mathrm{p}<0.05, * *$ highly significant at $0.01>\mathrm{p}>0.001, * * *$ highly significant at $\mathrm{p}<0.0001$, NS (non-significant). Mean values in a column followed by the same letter are not significantly different. Mean values in a column followed by a different letters are significantly different for $\alpha=0.001 \%$. 


\section{Figures}
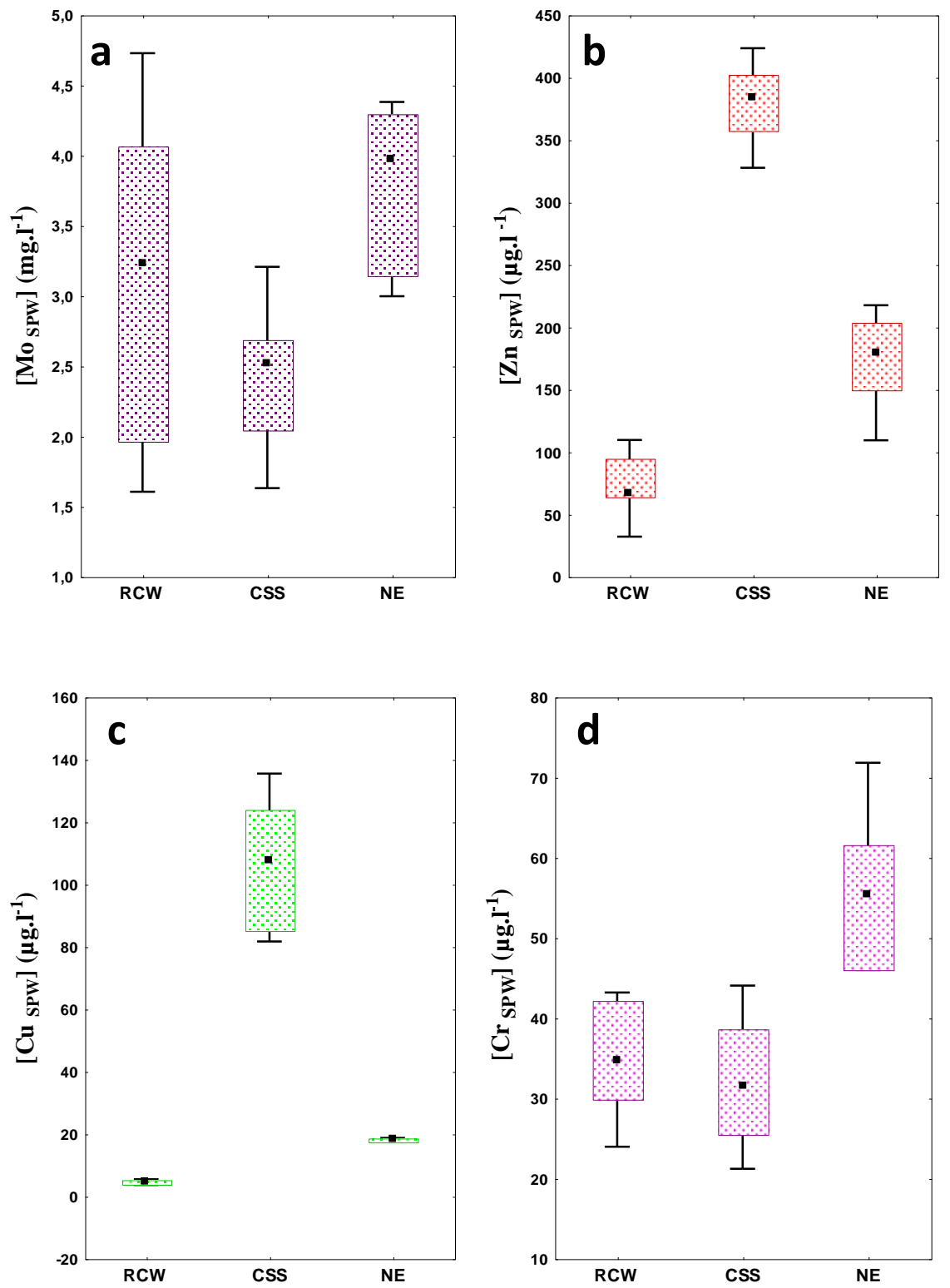

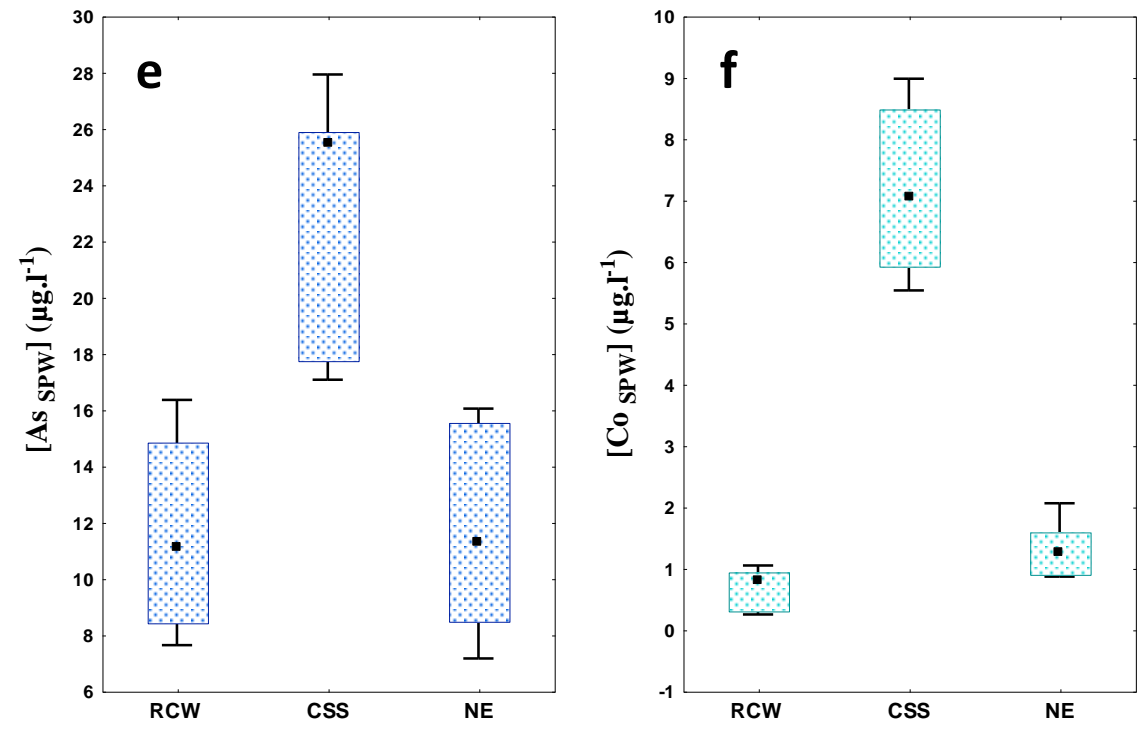

Figure 1. Concentrations of $\mathrm{Mo}, \mathrm{Zn}, \mathrm{Cu}, \mathrm{Cr}$, As and Co in the SPW and intensity of Cr. Values are $\bullet$ Median, $25 \%-75 \% \pm$ T Min-Max (n=9). 

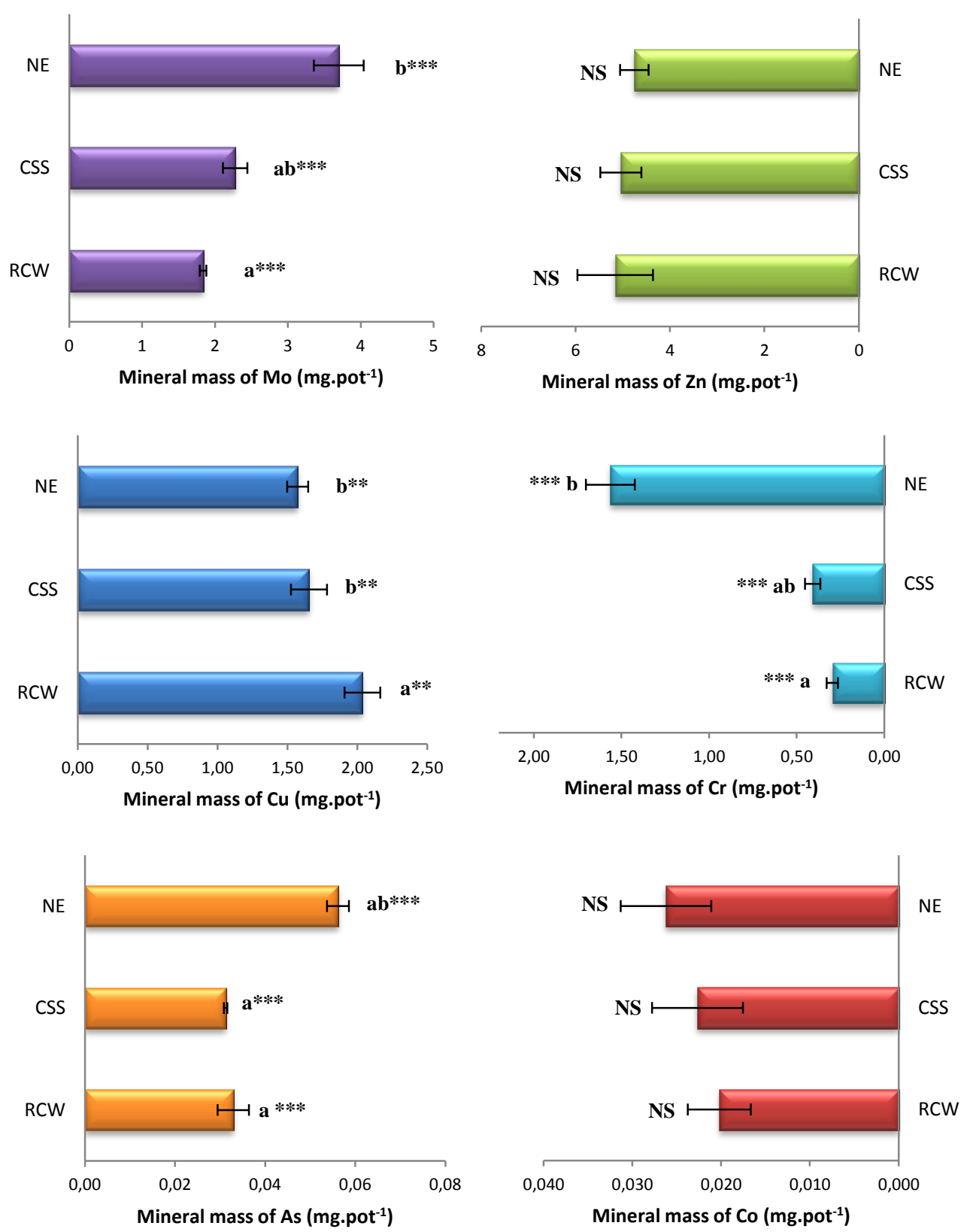

Figure 2: Mineral masses of $\mathrm{Zn}, \mathrm{Cu}, \mathrm{Cr}$, As and $\mathrm{Co}$ in the bean primary leaves. Values are mean \pm standard deviation $(n=9)$. Different letters on bar graphs indicate a significant difference $(p<0.05)$. 